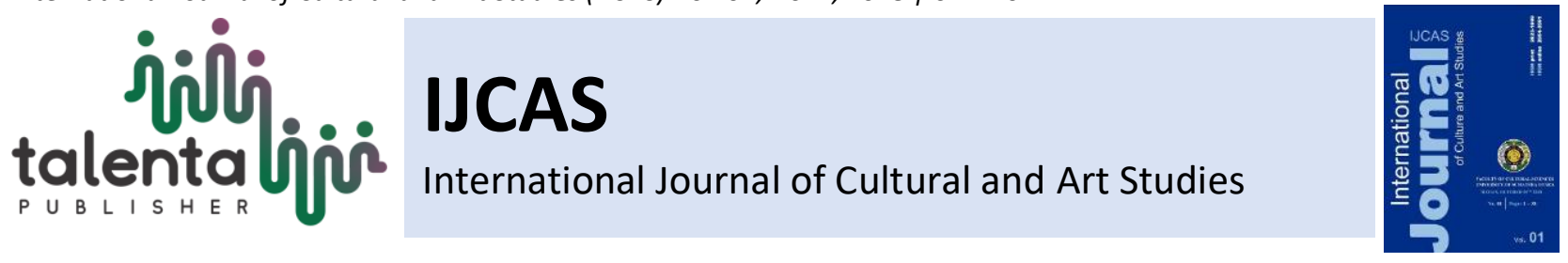

\title{
Intimate Language Variety in Animation Movie of Danshi Koukousei No Nichijou by Yasunobu Yamauchi
}

\author{
Mhd Pujiono $^{1^{*}}$ Taulia $^{2}$, Noriah Mohamed ${ }^{3}$ \\ ${ }^{1}$ Faculty of Cultural Studies, Universitas Sumatera Utara \\ ${ }^{2}$ University of Harapan, Medan \\ ${ }^{3}$ School of Humanities, Universiti Sains Malaysia
}

\begin{abstract}
This research elaborates language variety particularly in intimate language in Japanese animation movie Danshi Koukousei no Nichijou Episode Joshi Kousei wa Ijou High School Girls are Funky, the work of Yasunobu Yamauchi. In order to reveal the intimate language variety, Tomisaka theory was used [1] which highlights about the change in noun and sentence within intimate language variety. The method applied was descriptive qualitative method. The result of this research was the finding of language variety such as noun and verb change, and particle omission in sentences in that animation movie.
\end{abstract}

Keyword: Animation Movie, Intimate Language Variety, Language Variety, Sociolinguistic

Received 01 May 2018 | Revised 21 July 2018 | Accepted 11 August 2018

\section{Introduction}

Commonly, a language possesses a system and sub-system comprehended by the speakers. However, since those speakers reside in the environment where the language speakers are varied, somehow the presence of the language uniformity does not occur. It creates a variety within the language. Language variety occurs when there is a social interaction in the society.

Reference [2] states that language variety must be differentiated based on the speakers and the users. Speakers signify: who is the user of the language? Where does the language user reside? How is the language user social status in the society? What is the sex of the language user? Moreover, when is the language spoken? Based on this explanation, it is obvious that the discussion of language variety is an inseparable thing from the social state of the speakers; hence, this discussion is listed in the study of sociolinguistic.

The user, the speaker and the situation classify language variety based on the sociolinguistic. Based on the users, there is an intimate language in language variety. There is casual language

\footnotetext{
*Corresponding author at: Department of Japanese Literature, Faculty of Cultural Studies, Universitas Sumatera Utara, Jalan Universitas No. 19, Medan 20155, Indonesia

E-mail address: mhd.pujiono@usu.ac.id
} 
consisting of idiolect, dialect and sociolect. The situation can be formal language, frozen language, consultative language, casual language and intimate language [3].

Intimate language is a variety of language utilized amongst speakers who have very close relationship such as family members or best friends. This explains why this type of variety is very dominant in the daily life.

The forms of intimate language variety can be seen as well in various media such as novel, comic, animation, movie and etc. This research would elaborate the type of initimate language variety in Japanese animation movie entitled Danshi Koukousei no Nichijou, Yasunobu Yamauchi's piece of work produced in 2012.

The idiosyncracy of this movie is the prevailing depiction of senior high school students' life in Japan which use intimate language variety in the conversation. The context occured in the conversation shows the process of shortening the sentences and the change of noun and verb.

\section{Theoretical Frameworks}

\subsection{Sociolinguistic}

Sociolinguistic consists of two words, namely socio and linguistic. Linguistics is a study dealing with discovering and comprehending language and its feature such as utterances, words, and sentences, and the relationship amongst those features, including the formation of those features. Meanwhile the word socio means the relationship with the society. Thus, sociolinguistics can be defined as a study or discussion about language and its connection with the language users happened to be part of society [2].

Sociolinguistics shows the position of a language amongst its speakers within the society. This means sociolinguistic views language as social system, communication system and as a part of the society. Hence, the language and its users are not observed individually, but holistically with every single activity occurs in the society.

Fishman explains sociolinguistics as follows:

Sociolinguistic is the study of the characteristics of language varieties, the characteristics of the functions, and the characteristics of their speakers as these three constantly interact, change and change one another within a speech community. [4]

Sociolinguistic is an interdisciplinary study elaborates the influence of culture on how a language being spoken. In this case, language has a very strong tie with an area or region as the 
subject or the language behavior as interaction and communication tools amongst the groups [2].

Social identity of the speakers/ users can be revealed from the utterances or statements and the relationship with other speakers. The variety level and the linguistic style are defined by various political functions and political language and by the presence of code ability level, which are also varied for its social functions. In sociolinguistic, asserted by [3] language variety or language style can be classified into:

1. Formal language style (use wise) is one of the language styles utilized based on the use, or also well known as register. This variation is usually being used based on the realm of the use, such as literature, journalistic, militarism, agriculture, economic, trade, education etc.

2. Informal language style (speaker wise), which is divided into three parts:

a. Language variety called as idiolect is used individually.

b. Language variety called as dialect is determined based on the speaker of group living in certain areas or in one area.

c. The status, group and social class of the speaker determine language variety called as sociolect.

3. Language style determined and used by the situation is divided into five (5) types:

a. Formal language, is a language variety used in state official speech, office meeting, correspondence, textbooks and other subjects.

b. Frozen language, is a language variety used in official ceremonies.

c. Consultative language, is a variety language used at schools, meetings or in a conversation.

d. Casual language, is a language variety used in casual situation among families or close friends.

e. Intimate language

\subsection{Intimate Language}

Intimate language is one of language varieties spoken amongst people who have a very close relationship. This language variety is marked by incomplete use of language, shorts and non- 
proficient. This conversation happens amongst participants who know each other well and possess the same knowledge [5]. In intimate language variety, situational utterance is needed to be scrutinized. That simply refers to how the speakers speak, to whom they speak, which language they use, where do they speak and what do they talk about. Eventually, this intimate language variety can be exercised properly.

Intimate language variety is divided into two formations of noun transformation and verb or sentence transformation or sentence [1].

1. Noun Transformation

$\begin{array}{lll}\text { Word Origin } & & \text { Transformation into a shorter word } \\ \text { Tokoro } & \rightarrow & \text { Toko } \\ \text { Keredomo } & \rightarrow & \text { kedo } \\ \text { Sumimasen } & \rightarrow & \text { suimasen } \\ \text { Watashi } & \rightarrow & \text { atashi (used only by woman) } \\ \text { Anata } & \rightarrow & \text { anta } \\ \text { Kono aida } & \rightarrow & \text { konaida } \\ \text { Dochira } & \rightarrow & \text { docchi } \\ \text { Kocchira } & \rightarrow & \text { kocchi } \\ \text { Soccgira } & \rightarrow & \text { socchi } \\ \text { Achira } & \rightarrow & \text { acchi } \\ \text { Dokoka } & \rightarrow & \text { dokka } \\ \text { Totemo } & \rightarrow & \text { tottemo } \\ \text { Sugoku } & \rightarrow & \text { suggoku } \\ \text { Bakari } & \rightarrow & \text { bakkari } \\ \text { Yohodo } & \rightarrow & \text { yoppodo } \\ \text { ckute } & \rightarrow & \sim \text { kutte } \\ \text { Amari } & \rightarrow & \text { annmari } \\ \text { Onaji } & \rightarrow & \text { onnaji } \\ \text { Kore wa } & \rightarrow & \text { Korya } \\ \text { Sore wa } & \rightarrow & \text { Sorya } \\ \text { Are wa } & \rightarrow & \text { Arya } \\ \sim \text { reba } & \rightarrow & \text { rya } \\ \text { Jyan } & \rightarrow & \text { jyanai } \\ & & \end{array}$

2. Sentence Transformation

Sentence Origin

$\sim$ te kudasai

naide Kudasai

tara dou desuka

ba ii desuka

$\sim$ te wa doudesu ka

$\sim$ nakereba naranai

nakya naranai

nakutewa ikenai

nakucha ikenai

$\sim$ naito ikenai

$\sim$ to kikimashita

$\sim$ to imashita

$\sim$ to imashita $k a$

Transformation into shorter sentence

$$
\begin{aligned}
& \rightarrow \quad \sim t e \\
& \rightarrow \quad \sim \text { naide } \\
& \rightarrow \quad \sim \text { tara } \\
& \rightarrow \quad \sim \sim b a \\
& \rightarrow \quad \sim \text { te wa } \\
& \rightarrow \quad \sim \text { nakereba } \\
& \rightarrow \quad \sim \text { nakya } \\
& \rightarrow \quad \sim \text { nakutewa } \\
& \rightarrow \quad \sim \text { nakucha } \\
& \rightarrow \quad \sim \text { naito } \\
& \rightarrow \quad \sim \sim t t e \\
& \rightarrow \quad \sim t t e \\
& \rightarrow \quad \sim t t e \text { ? }
\end{aligned}
$$


$\sim$ to iu no wa nan desuka

$\sim$ Ikanai

itte iru no? $\sim$ tte?

Ikan

itten no?

\section{Method}

This research applied descriptive qualitative method. The obtained data were analyzed based on Japanese intimate language variety that has correlation with situational utterance based on related theory. The data were obtained from the natural features of the scripts [6]. The processes conducted in this research were collecting the data, analyzing the data and presenting the data [7].

The data used in this research were conversation scripts of intimate language variety used amongst men and women in animation movie of Danshi Koukousei no Nichijou Episode Joshi Kousei wa Ijou High School Girls are Funky by Yamauchi in episode 11 entitled 闘争 'Tousou 'A Fight'.

Data collection was conducted by applying listening method followed by writing technique [8]. The listening method in this animation movie was conducted by playing, listening and stopping the conversation in the animation movie. This method then followed by jotting down the words based on the characters and making the transcription of verbal text contained in animation movie [7]. The data was being transformed into transcription from spoken Japanese into Roman alphabet.

After collecting the data, then the next step was analyzing the data. According to [9], there are some types of activites done in analyzing the data, they are:

\section{Data Reduction}

The data were conversation scripts in animation movie Danshi Koukousei no Nichijou Episode Joshi Kousei wa Ijou High School Girls are Funky by Yasunobu Yamauchi [10] in episode 11 which were collected and written meticulously. Further, the data were being classified based on intimate language variety. In order to differentiate the intimate language variety, the coding system was used based on the transformation of the verb and the noun. The transformation of the noun was marked by the blue color and the verb was marked by the yellow color.

\section{Data Presentation}

The presentation of qualitative data in this research was the data of spoken Japanese conversation in animation movie of Danshi Koukousei no Nichijou Episode Joshi Kousei wa Ijou High School Girls are Funky. The data were presented orderly started with the title, episode, casts, location, situation and synopsis in order to ease the analysis. 


\section{Conclusion verification}

After reducing and presenting the data in animation movie of Danshi Koukousei no Nichijou Episode Joshi Kousei wa Ijou High School Girls are Funky, then conclusion was being proceeded. The conclusion which is the result of data reduction and data presentation must be correct and appropriate. In order to prove this, the data verification is needed.

\section{$4 \quad$ Result and Discussion}

The following data were the transcription of episode 11 of animation movie Danshi Koukousei no Nichijou Episode Joshi Kousei wa Ijou High School Girls are Funky titled 闘争 'Tousou 'A Fight.' The casts are Yanagi, Ikushima and Habara. The location of the conversation is on the street and the situation is informal one.

This episode was begun when Yanagi, Ikushima and Habara were on their way home. Yanagi asked Ikushima and Habara who were amongst them was the strongest. Ikushima thought that question was a challenge to be proven by a fight. However, Habara seemed objected with that thing and asked them to stop. Ikushima and Yanagi mocked Habara for being so afraid of getting lost. Ikushima then asked how the rule of the fight is. Innocently, Habara answered that the fight needed no rules. Yanagi and Ikushima then suddenly were getting afraid of remembering Habara's past for being a very demonic woman. They eventually cancelled the fight. Habara became so relieved and threw a big stone from her hand. This made Yanagi and Ikushima became more afraid because at the end they realized that Habara had been keeping a big stone with her since the beginning.

The conversation transcript in the anime:

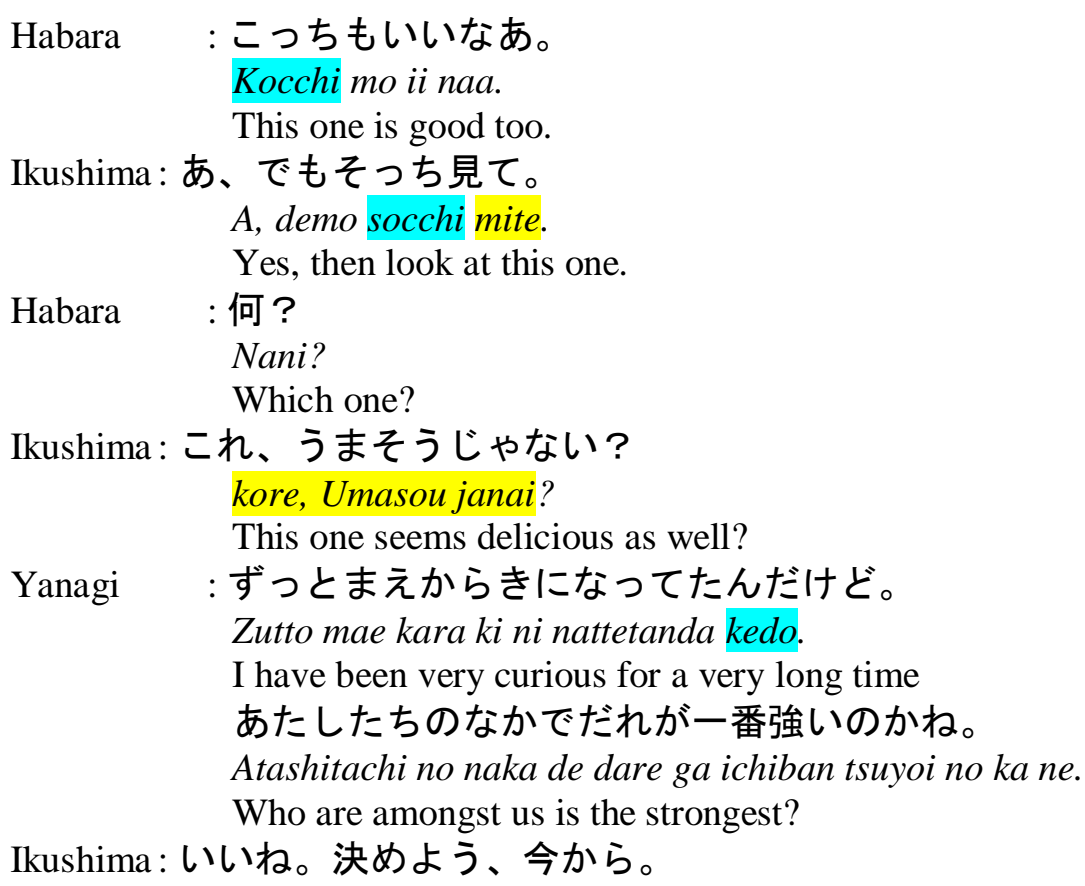


Ii ne. Kimeyou, ima kara.

That sounds good. Let's find out now.

Habara : ちょっと待ってよ。何言ってんの?

Chotto matte yo. Nani ittenno?

Wait for a moment. What are you talking about?

Yanagi：うちらのいつまでも仲良しすごくやってるわけにもいかんし。 Uchira no itsu made mo nakayoshi sugoku yatteru wake ni mo ikanshi.

We can't pretend to be walking like this as we are very close.

Habara : 何がいかんのよ。

Nani ga ikanno yo.

What can't be done?

やめようよ。意味わかんないし。だれが強いかなんてどうでも いいよ。

Yameyou yo. Imi wakannai shi. Dare ga tsuyoi ka nante dou demo ii yo.

ughh! You have no class and elegance! Don't ever think who's the strongest!

Yanagi : ずいぶんと余裕じやねえか、化け物。

Zuibun to yoyuu janee ka, bakemono.

It seems you are very relax, devil!

Ikushima : 負けるのが怖いんだろう。

Makeru no ga kowaindarou.

I bet you must be afraid of getting lost, isn't it?

Habara

: もう. .

Мou...

ouchh...

Ikushima : ね?ルールはどうする?

Ne? Ruuru wa dou suru?

so? What's the rule of the fight?

Yanagi : そうだな。

Sou da na.

Yes, that one.

Habara

へ?ちょつと待て。今から戦うんでしょう。なんでルールが必要なの ?

He? Chotto mate. Ima kara tatakaundeshou. Nande ruuru ga hitsuyou nano?

He? Wait a moment? Aren't we starting to fight? Are we? Why do we need

Yanagi \& rules?

Ikushima: へ?

$\mathrm{He}$ ?

$\mathrm{He}$ ?

Yanagi

戦いにおいて最悪の事態を避けるためルールを設ける。そのがいねん がこのきょうじょには理解できないのである。

Tatakai ni oite saiaku no jitai o sakeru tame ruuru wo moukeru. Sono gainen ga kono kyoujo ni wa rikai dekinai no dearu.

In order to avoid the worst scenario when we fight, we need rules and this devilish girl can understand concepts and these.

闘争の意味、スポーツとして各闘技を習った私たちとはそれが 根本的に違っていた。やだなあ。几談だよ、はばら。

Tousou no imi, supootsu toshite kakutougi naratta watashitachi to wa sore ga konponteki ni chigatte ita. Yada naa. Joudan dayo, Habara. 
The meaning of the disagreement that we understand differently is by understanding the concept through respecting every athlete of martial arts. What is this? We are just joking, Habara!

Ikushima: 本気にしないでよ、もう. .

Honki ni shinaide yo, mou...

Don't be so serious oh come one..

Habara : なんだ?冗談か。

Nanda? Joudan ka.

What? That's just joking right?

Yanagi : そういって、彼女は大きな石を投げ捨てたのだった。

Sou itte, kanojo wa ookina ishi o nagesuteta no datta.

While talking that thing, she threw a very big stone away.

From the result of the conversation transcript in episode 11 of animation movie Danshi Koukousei no Nichijou, Joshi Kousei wa Ijou High School Girls are Funky, it was found that there are various intimate language variety as presented table 1.

Tabel 1. Form of Intimate Language Variety in Episode 11 Animation Movie Danshi Koukousei no Nichijou, Joshi Kousei wa Ijou High School Girls are Funky

\begin{tabular}{|c|c|c|c|}
\hline Conversation text & $\begin{array}{c}\text { The } \\
\text { transformation } \\
\text { of noun }\end{array}$ & Conversation text & $\begin{array}{l}\text { Transformation of verb } \\
\text { or sentence shortened }\end{array}$ \\
\hline $\begin{array}{ll}\text { - } & \text { Kocchi mo ii } \\
\text { naa. } \\
\text { - } \\
\text { A, demo socchi } \\
\text { mite } \\
\text { - Zutto mae kara ki } \\
\text { ni nattetanda } \\
\text { kedo }\end{array}$ & $\begin{array}{l}\text { - Kocchi a } \\
\text { kochira } \\
\text { - Socchi } \\
\text { supposed to } \\
\text { be sochira } \\
\text { - Kedo } \\
\text { supposed to } \\
\text { be keredo }\end{array}$ & $\begin{array}{l}\text { - A, demo socchi } \\
\text { mite } \\
\text { - kore, Umasou } \\
\text { jyanai? } \\
\text { - Chotto matte yo. } \\
\text { Nani ittenno? } \\
\text { - Uchira no itsu } \\
\text { made mo } \\
\text { nakayoshi sugoku } \\
\text { yatteru wake ni mo } \\
\text { ikanshi. } \\
\text { - Nani ga ikan no yo } \\
\text { - Yameyou yo. Imi } \\
\text { wakannai shi. } \\
\text { - Zuibun to yoyuu } \\
\text { janee ka. } \\
\text { - He? Chotto matte. } \\
\text { Ima kara } \\
\text { tatakaundeshou } \\
\text { - Honki ni shinaide } \\
\text { yo, mou... } \\
\text { - Sou itte, kanojo wa } \\
\text { ookina ishi o } \\
\text { nagesuteta no } \\
\text { datta. }\end{array}$ & $\begin{array}{l}\text { - Mite supposed to be mite } \\
\text { kudasai. } \\
\text { - Supposed to be kore wa } \\
\text { umasou jyanai } \\
\text { - Supposed to be chotto } \\
\text { matte kudasai yo. Nani o } \\
\text { shite iru no? } \\
\text { - Ikanshi supposed to be } \\
\text { ikanaishi } \\
\text { - Ikan supposed to be } \\
\text { ikanai. } \\
\text { - Wakannai supposed to be } \\
\text { wakaranai } \\
\text { - Jyanee supposed to be } \\
\text { jyanai. } \\
\text { - Supposed to be He? } \\
\text { Chotto matte kudasai } \\
\text { - Supposed to be Honki ni } \\
\text { shinaide kudasai yo. } \\
\text { - Sou itte supposed to be } \\
\text { sou iu koto itte. }\end{array}$ \\
\hline
\end{tabular}


From table 1, the intimate language variety can be seen from noun kocchi, socchi and kedo. These nouns have been transformed from kochira, sochira and keredo. Then verb and the sentence were transformed into:

(1) Chotto matte yo. Nani ittenno?

Wait a moment. What are you talking about?

(2) Nani ga ikan no yo

What can't be done?

In sentence (1) the complete form of verb matte is matte kudasai, but it has shortened. Then the word ittenno is the shortened version of itte iru no? The word ikan in sentence (2) is the shortened version of ikanai.

The word changing or transformation in this animation movie is in accordance with Tomisaka's opinion (1997) states that the intimate language variety happens in the transformation of noun, verb or even sentence.

The shortened sentence within the intimate language variety was also found in this animation movie. The shortened sentence happened by omitting the particle in the sentence. It happened in sentence (1) nani ittenni? which is supposed to be nani o itte iru no? and eventually omitted the particle ' $\mathrm{o}$ ' in the sentence.

\section{Conclusion}

Variety or language style is one of discussions in sociolinguistic study which highlights the relation amongst language, the environment and the speakers. One of the variations is the intimate language variety. This intimate language variety can be found in various media such as novel, comic, animation, movie, etc. In animation movie of Danshi Koukousei no Nichijou Episode Joshi Kousei wa Ijou High School Girls are Funky, a piece of work by Yasunobu Yamauchi in episode 11, it was found that the intimate language variety has many forms of trasnformation in the noun, verb and sentence in Japanese language. Furthermore, it was also found a particle omission in the sentence in intimate language variety.

\section{REFERENCES}

[1] Y. Tomisaka, Nihongo no Dansei to Josei no Kotoba, Tokyo: Aruku, 1997.

[2] A. Chaer \& L. Agustina, Sosiolinguistik Perkenalan Awal. Edisi Revisi, Jakarta: PT. Rineka Cipta, 2004.

[3] J. Martin, Variety of Language, London: Longman, 1987.

[4] J.A. Fishman, The Sociology of Language, Rawly Massachussett: Newbury House, 1972.

[5] R. Machali, Variasi Bahasa. Bandung, KAIFA, 2009. 
[6] F. Djajasudarma, Metode Linguistik Ancangan Metode Penelitian dan Kajian, Bandung: PT Eresco. 1993, pp.7.

[7] Sudaryanto, Metode Linguistik Kedua: Metode ke Arah Memahami Metode Linguistik, Yogyakarta: Gadjah Mada University Press, 1993.

[8] Mahsun, Metode Penelitian Bahasa, Jakarta: Raja Grafindo Persada. S, 2005.

[9] M. B. Miles \& A.M. Hubeman, Analisis Data Kualitatif, Jakarta : UI PRES, pp. 16-20, 2014.

[10] Y. Yamauchi, Danshi Koukousei no Nichijou, Tokyo: Square Enix, Sunrise \& Korabu Sakuhin. 2012. 